\title{
Perbedaan Pola Channeling dan Executing pada Pembiayaan Linkage Program di Bank Syariah Mandiri Cabang Salatiga
}

\author{
Febri Antika Sonya Harum Dapta \\ Sekolah Tinggi Agama Islam Negeri (STAIN) Salatiga \\ antika_sonya@yahoo.co.id
}

\begin{abstract}
:
The purpose of the research was to determine the procedures and schemes of executing and channeling system of Linkage Program in Syariah Mandiri Bank Branch Salatiga, and to know the difference between the two systems. The method I used is descriptive qualitative method. The results of this study concluded that procedures and schemes of executing and channeling system different, the difference lies in the role of Linkage in the process of filing financing. While other differences largely lies in who their customers, the role of the Linkage institution, information about the end user, the view procedures in terms of end-user, provisions Debt to Equity Ratio (DER) of each system, financing decisions of end user, end user guarantees storage, document storage end user financing, and the type of contract used. Of these differences, when viewed from the perspective of end users, a much more easier and simpler to implement is executing system, the system is therefore more desirable.
\end{abstract}

Keywords: Linkage Program, executing system, channeling system

\begin{abstract}
Abstrak:
Tujuan diadakan penelitian ini adalah untuk mengetahui prosedur dan skema Linkage Program pola executing dan channeling di Bank Syariah Mandiri Cabang Salatiga, dan untuk mengetahui perbedaan di antara kedua pola tersebut. Metode yang penulis gunakan yaitu metode deskriptif kualitatif. Hasil penelitian ini menyimpulkan bahwa prosedur dan skema dari pola executing dan channeling itu berbeda. Perbedaannya terletak pada peran lembaga Linkage dalam proses pengajuan pembiayaan. Sedangkan perbedaan lainnya secara garis besar terletak pada siapa nasabahnya, peran lembaga
\end{abstract}


Linkage, informasi tentang end user, pandangan prosedur dari segi end user, ketentuan DER dari masing-masing pola, keputusan pembiayaan end user, penyimpanan jaminan end user, penyimpanan dokumen pembiayaan end user, dan jenis akad yang digunakan. Dari perbedaan tersebut, jika dilihat dari sudut pandang end user, pola yang lebih mudah dan sederhana untuk diterapkan adalah pola executing, oleh karena itu pola tersebut lebih diminati.

Kata kunci: Linkage Program, pola executing, pola channeling.

\section{Pendahuluan}

Usaha Kecil dan Menengah (UKM) yang dipahami sebagai salah satu pondasi perekonomian negara telah berkembang cukup signifikan di Indonesia. Saat ini, jumlahnya mencapai 52 juta dan menyerap tenaga kerja hampir 90 juta orang. Munculnya banyak UKM ini sangat membantu perekonomian negara terutama penghasilan dari Produk Domestik Bruto (PDB) Nasional non migas hingga sekitar 60\% sejak tahun 2001 sampai dengan 2010 secara konsisten, dan mengalami sedikit penurunan setelahnya (Januar: 2012).

Saat ini bank lebih senang mendanai Usaha Mikro, Kecil, dan Menengah (UMKM) dikarenakan keuntungan yang dihasilkan oleh usahausaha tersebut berkembang secara meningkat. Berdasarkan hasil survei Bank Indonesia di tahun 2011, dari 11.000 unit usaha sampel yang diteliti dan tersebar pada sebelas wilayah, menunjukkan $84,4 \%$ mencatat laba usaha di atas $10 \%$. Dari 11.000 unit usaha tersebut, $35 \%$ di antaranya memiliki profit margin lebih dari 35\% (Basuki: 2011).

Hal tersebut bertolak belakang dengan pandangan masyarakat pada umumnya yang menganggap bahwa UMKM itu tidak bisa bertahan lama atau rawan merugi.

Di sisi lain, Bank umum maupun Bank Umum Syariah (BUS) membutuhkan lembaga keuangan lain yang cakupannya lebih kecil dan letaknya lebih dekat dengan masyarakat terutama yang berada di pelosokpelosok daerah untuk menyalurkan dana bagi UMKM. Lembaga keuangan lain yang dimaksud adalah lembaga Linkage yaitu, BPR/BPRS, koperasi/ 
KJKS, serta BMT.

Dalam penelitian ini penulis lebih menyoroti penyaluran dana BUS kepada lembaga Linkage. Merujuk peraturan Bank Indonesia No. 8/22/PBI/ 2006, tentang Kewajiban Penyediaan Modal Minimum bagi Bank Perkreditan Rakyat Berdasarkan Prinsip Syariah, maka sangat tepat jika ada program pinjaman oleh Bank Umum Syariah (BUS) kepada BPRS. BUS mengadakan pembiayaan Linkage Program yang disalurkan melalui lembaga Linkage. Pembiayaan dimaksud untuk memudahkan penyaluran pembiayaan UMKM.

Pada perkembangannya sudah banyak bank-bank umum dengan prinsip syariah yang melaksanakan Linkage Program, di antaranya Bank Syariah Mandiri, Bank Muamalat, BNI Syariah, Bank Danamon Syariah, dan lain sebagainya. Mereka menyalurkannya kepada lembaga Linkage di wilayah yang mampu menjangkau UMKM sampai ke daerah pelosok. Untuk Bank Syariah Mandiri, mulai Juni 2012 ada ketentuan intern yang melarangnya menyalurkan Linkage Program kepada BPR.

Penelitian ini memfokuskan pada perkembangan Linkage Program yang telah dilakukan oleh Bank Syariah Mandiri Cabang Salatiga kepada lembaga Linkage yang ada di sekitar kota Salatiga.

Sekilas kesan dari nasabah baik lembaga Linkage maupun end user tentang pelaksanaan Linkage Program, mereka merasa sangat terbantu. Perekonomian di daerah-daerah pelosok dapat meningkat, dan kesejahteraan masyarakat juga mengalami peningkatan (wawancara dengan Bapak Supardi, nasabah pembiayaan Linkage Program, pada 22 juni 2012, pukul 14.00 WIB).

Menurut jenisnya, Linkage Program dibagi menjadi 3, yaitu Linkage dengan pola executing, channeling, dan joint financing. Namun yang banyak digunakan di daerah Salatiga dan sekitarnya adalah Linkage dengan pola executing dan pola channeling.

\section{Rumusan Masalah}

Rumusan masalah yang terkait dengan kasus yang akan dibahas pada penelitian ini, di antaranya tentang bagaimana skema, prosedur dan analisis pola executing dan channeling dan apa perbedaan kedua pola tersebut pada pembiayaan Linkage Program di Bank Syariah Mandiri Cabang Salatiga, 
sehingga menentukan minat nasabah terhadap pola pembiayaan Linkage Program yang dipilih.

\section{Tujuan dan Kontribusi}

Dengan demikian, tujuan yang ingin dicapai adalah gambaran skema pembiayaan Linkage Program baik pola executing maupun channeling, selain itu juga penjelasan mengenai prosedur, analisis, serta perbedaan kedua pola tersebut.

Penelitian ini memberikan kontribusi bagi beberapa pihak. Bagi STAIN Salatiga yaitu memperkenalkan STAIN Salatiga kepada masyarakat luar khususnya Program Studi DIII Perbankan Syariah dan sebagai tambahan referensi literatur serta informasi khususnya bagi mahasiswa STAIN Salatiga Program Studi DIII Perbankan Syariah. Sedangkan bagi pembaca yaitu sebagai tambahan wawasan tentang perbedaan pola pembiayaan Linkage Program terutama pola channeling dan executing di Bank Syariah Mandiri (BSM) Cabang Salatiga dan sebagai bahan referensi pertimbangan dalam pengajuan pembiayaan.

\section{Studi Pustaka}

Terkait dengan penelitian yang diteliti oleh penulis, ada beberapa telaah pustaka dari penelitian-penelitian sebelumnya yang telah dibuat sehingga dapat dijadikan bahan pertimbangan maupun pembeda bagi penelitian ini.

Kumara (2010), dalam penelitiannya yang berjudul “Analisis Uji Beda Kinerja BPR yang Mengikuti Linkage Program dengan BPR yang Tidak Mengikuti Linkage Program pada Wilayah DPC Depok" menyatakan bahwa keberadaan Linkage Program di area Depok tidak dapat mendorong kinerja BPR terhadap ROA, LDR dan NPL menjadi lebih baik. Penelitian ini tidak menunjukkan pola apa yang dipakai dalam pelakasanaan Linkage Program.

Misbach (2010), dalam penelitiannya yang berjudul "Sinergi Antara Lembaga Keuangan Syariah dalam Memajukan Usaha Kecil" memaparkan bahwa Linkage Program yang dilakukan oleh bank kepada BPRS dan BMT 
sangat bermanfaat, di antaranya bagi bank syariah: yakni akan lebih memperbesar akses masyarakat untuk memperoleh pelayanan pembiayaan dari bank syariah; biaya transaksinya akan lebih kecil jika dibandingkan dengan penyaluran pembiayaan secara langsung kepada tiap unit UMKM yang nilainya kecil; biaya operasional perbankan akan lebih efisien karena bank-bank syariah tidak perlu membuat kantor cabang atau kantor pelayanan sampai ke pelosok-pelosok daerah. Bagi BPRS dan BMT: keberadaan Linkage Program sudah barang tentu akan meningkatkan ketersediaan dana yang akan disalurkan kepada masyarakat khususnya UMKM. Linkage program akan menjadi solusi bagi masalah struktural BPRS dan BMT sebagai lembaga keuangan mikro.

Nabhan (2012), dalam disertasinya yang berjudul "Pengembangan Kapabilitas Kolaborasi Dinamis dan Pengaruhnya Terhadap Kinerja Bisnis”, studi dilakukan pada Koperasi Jasa Keuangan Syariah di Jawa Tengah. Penelitiannya menunjukkan orientasi kolaborasi dan harapan keberlanjutan kolaborasi berpengaruh positif dan signifikan terhadap fleksibilitas organisasi. Disertasi ini lebih mengacu pada keberlanjutan hubungan antara 2 perusahaan yang saling bekerja sama sehingga menghasilkan kinerja yang lebih baik dan keberlanjutan hubungan kerja berikutnya. Dalam hal ini seperti halnya manfaat kerja sama antara bank syariah dengan lembaga Linkage yang melakukan kerja sama.

Penelitian dari Farika (2008) yang berjudul "Aplikasi Pembiayaan Kongsi Pemilikan Rumah Syariah Pada Baitul Mal Wat Tamwil (BMT) Ahmad Yani" menyimpulkan bahwa analisis pembiayaan yang diterapkan pada BMT Ahmad Yani menggunakan sistem scoring setiap kriteria ada nilainya. Pembiayaan pemilikan rumah syariah pada BMT Ahmad Yani menggunakan dua pola yaitu pola chaneling dan pola executing. Pada pola chaneling ini pihak BMT hanya sebagai penyalur saja dan tanggung jawab ditanggung penuh oleh pihak BMI. Sedangkan pada pola executing pihak Bank Muamalat Indonesia (BMI) tidak hanya sebagai penyalur saja, tetapi juga bertanggung jawab penuh atas pembiayaan pemilikan rumah. Hal ini menunjukkan bahwa Linkage mencakup pembiayaan rumah juga. Ini merupakan suatu sample dari penerapan pola executing maupun channeling. 


\section{Kerangka Teoritik}

Dasar hukum Linkage Program yaitu: Undang-Undang No.21 tahun 2008 tentang Perbankan Syariah; Peraturan Bank Indonesia No. 9/17/PBI/ 2007, tanggal 4 Desember 2007 tentang Sistem Penilaian Tingkat Kesehatan BPR Berdasarkan Prinsip Syariah; Peraturan Bank Indonesia No. 8/18/PBI/ 2006, tanggal 5 Oktober 2006 tentang Kewajiban Penyediaan Modal Minimum BPR; Peraturan Bank Indonesia No. 6/17/PBI/2004, tanggal 1 Juli 2004 tentang Bank Perkreditan Rakyat Berdasarkan Prinsip Syariah; Peraturan Bank Indonesia No. 8/22/PBI/2006, tentang Kewajiban Penyediaan Modal Minimum bagi Bank Perkreditan Rakyat Berdasarkan Prinsip Syariah; Surat Edaran Bank Indonesia No. 3/9/BKr, tanggal 17 Mei 2001 perihal Petunjuk Pelaksanaan Pemberian Kredit Usaha Kecil (KUK); Anggaran dasar PT Bank Syariah Mandiri; Opini Dewan Pengawas Syariah BSM No. 9/003/ DPS, tanggal 12 Februari 2007 perihal opini Dewan Pengawas Syariah tentang Penyaluran Pembiayaan Secara Channeling kepada BPR dan Layanan Jasa Transfer atas Pembiayaan Transaksi Riba; Kebijakan Pembiayaan PT Bank Syariah Mandiri; Kebijakan Manajemen Risiko PT Bank Syariah Mandiri; Kebijakan Sistem Pengendalian Intern PT Bank Syariah Mandiri; Pedoman Pembiayaan PT Bank Syariah Mandiri; dan Petunjuk Pelaksanaan Pembiayaan Mikro.

Sedangkan menurut Hosen (2008) dalil tentang Linkage Program dalam perbankan syariah di antaranya yaitu dlam surat Al-Baqarah (2): 282 sebagai berikut:

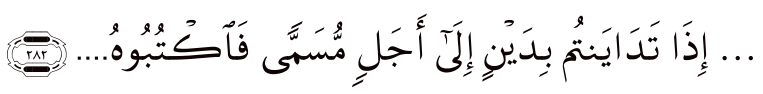

“...apabila kamu melakukan utang-piutang untuk waktu yang ditentukan, hendaknya kamu menuliskannya..."

HR Ahmad, Abu Dawud dan Hakim dari Abu Hurairah:

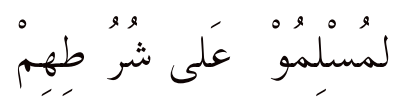

"Transaksi orang muslim itu sesuai dengan syarat-syarat antara mereka" 
Arifin (2002), menyebutkan bahwa pembiayaan (financing) yaitu memberikan fasilitas penyediaan dana untuk memenuhi kebutuhan pihakpihak yang kekurangan dana. Menurut sifat penggunaannya, pembiayaan dibagi menjadi dua, yaitu pembiayaan konsumsi dan produksi. Sedangkan menurut keperluannya, pembiayaan produktif dibagi menjadi pembiayaan modal kerja dan pembiayaan investasi.

Penelitian ini membahas tentang pembiayaan modal kerja. Pembiayaan modal kerja untuk BPRS/BMT/Koperasi adalah uang cash/cair. Lembaga keuangan tersebut selanjutnya disebut lembaga Linkage.

Adapun pembiayaan modal kerja yang diberikan kepada lembaga Linkage oleh Bank Syariah Mandiri Cabang Salatiga, yaitu pembiayaan Linkage Program. Pembiayaan ini merupakan kerja sama strategis bagi penyaluran pembiayaan kepada UMKM. Agar bisnis ini dapat berkembang, berjalan dengan baik, memiliki daya saing, dan terhindar dari kerugian yang tidak diinginkan, diperlukan penyempurnaan ketentuan yang selaras dengan perkembangan situasi yang ada.

Pembiayaan modal kerja Linkage Program bisa dilakukan dengan pola channeling dan executing. Channeling menggunakan akad wakālah dalam penandatanganan perjanjian kerja samanya. Sedangkan skim pembiayaannya mengikuti transaksi yang dilakukan, yaitu bisa wakālah wa al-muḍārabah/ mushārakah/murābaḥah/ijārah. Pembiayaan pola executing adalah pembiayaan UMK yang langsung diberikan bank kepada lembaga Linkage. Pembiayaan pola channeling adalah pembiayaan yang diberikan bank kepada UMK melalui lembaga Linkage yang bertindak sebagai agen/ wali. Pencatatan di bank sebagai pembiayaan ke UMK/end user dan di lembaga Linkage pada off balance sheet. Lembaga Linkage sebagai agen berhak menerima ujrah/fee.

Menurut Muhammad (2002: 304), pembiayaan secara luas berarti financing atau pembelanjaan, yaitu pendanaan yang dikeluarkan untuk mendukung investasi yang telah direncanakan, baik dilakukan sendiri maupun dijalankan oleh orang lain. Sedang dalam arti sempitnya, yaitu pendanaan yang dilakukan oleh lembaga pembiayaan, seperti bank syariah kepada nasabah. Kondisi yang seperti ini menjadikan istilah pembiayaan menjadi sempit dan pasif, hal ini dikarenakan keterbatasan pemahaman para 
pelaku bisnisnya.

Linkage Program adalah kerja sama bank umum dan Bank Perkreditan Rakyat yang dilandasi semangat kemitraan yang bersifat symbiosis mutualistic dengan tetap berorientasi pada aspek bisnis (Media BPR: 2012).

Menurut Sudarsono (2006: 113), executing disebut juga penyaluran dana investasi terikat, yang pengertiannya adalah suatu akad kerja sama usaha antara nasabah sebagai pengelola dana (muḍ̄ārib) dengan bank sebagai pemilik dana (șāhibu al-māil) di mana pemilik dana memberikan persyaratan tertentu dalam tujuan pembiayaan, sektor usaha, lokasi, dan persyaratan lainnya, serta bank ikut menanggung risiko pengelolaan dana. Apabila bank bertindak sebagai agen (channeling) dalam menyalurkan dana muḍārabah muqayyadah atau investasi terikat tetapi bank menanggung risiko atas penyaluran dana tersebut, maka pelaporannya dilakukan dalam neraca sebesar porsi risiko yang ditanggung oleh bank.

Dalam suatu analisis pembiayaan, menurut Muhammad, ada beberapa hal yang perlu diperhatikan (2002: 304-309) yaitu: 1) Pendekatan analisis pembiayaan, meliputi: pendekatan jaminan, karakter, kemampuan pelunasan, pendekatan dengan studi kelayakan, serta memperhatikan perannya sebagai lembaga intermediari keuangan; 2) Prinsip analisis pembiayaan, menggunakan prinsip 5 C, yaitu: Character, Capacity, Capital, Collateral, Condition; 3) Tujuan analisis pembiayaan, ada tujuan umum yaitu pemenuhan jasa pelayanan terhadap kebutuhan masyarakat dalam rangka mendorong dan melancarkan perdagangan, produksi, jasa-jasa, bahkan konsumsi untuk meningkatkan taraf hidup masyarakat dan tujuan khusus yaitu untuk menilai kelayakan usaha calon peminjam, menekan risiko akibat tidak terbayarnya pembiayaan, menghitung kebutuhan pembiayaan yang layak.

Prosedur analisis pembiayaan, menurut Muhammad (2002), memiliki aspek-aspek penting, yaitu: Berkas dan pencatatan; Data pokok dan analisis pendahuluan (Realisasi dan rencana pembelian, produksi dan penjualan); Jaminan; Laporan keuangan; Data kualitatif dari calon debitur; Penelitian data; Penelitian atas realisasi usaha; Penelitian atas rencana usaha; Penelitian dan penilaian barang jaminan; Laporan keuangan dan penelitiannya.

Sedangkan keputusan permohonan pembiayaan berasal dari bahan pertimbangan pengambilan keputusan dan wewenang pengambilan keputusan. 
Adapun aspek yang dianalisis meliputi aspek yuridis, aspek pemasaran, aspek teknis, aspek keuangan, dan aspek jaminan. Sedang alat analisis pembiayaan dapat berupa angket.

Beberapa hal yang perlu diperhatikan dalam perumusan hasil analisis pembiayaan yaitu identitas pemohon, identitas usaha, aspek pasar, sumber bahan baku, aspek pengelola, aspek ekonomi, permodalan, dan data keuangan.

Menurut petunjuk di Bank Syariah Mandiri perihal Pembiayaan Linkage Program melalui lembaga Linkage [Bank Perkreditan Rakyat (BPR) dan Bank Pembiayaan Rakyat Syariah (BPRS)], pembiayaan Linkage Program yang melibatkan lembaga Linkage merupakan kerja sama strategis bagi penyaluran pembiayaan UMK. Agar bisnis dapat terus berkembang, berjalan dengan baik, mempunyai daya saing, dan terhindar dari kerugian yang tidak diinginkan, diperlukan penyempurnaan ketentuan yang diselaraskan dengan perkembangan situasi yang ada.

Sasaran pembiayaan ini untuk lembaga Linkage, yaitu koperasi, BMT dan BPRS, dapat menggunakan pola executing dan channeling. Sedangkan untuk BPR hanya diperbolehkan menggunakan pola channeling.

Persyaratan yang harus dimiliki lembaga Linkage untuk pola executing dan channeling yaitu:

Tabel 2.1

Persyaratan Lembaga Linkage

\begin{tabular}{|l|l|l|l|}
\hline No & \multicolumn{1}{|c|}{ Kriteria } & \multicolumn{1}{|c|}{$\begin{array}{c}\text { Persyaratan Minimal lembaga } \\
\text { Linkage }\end{array}$} & $\begin{array}{l}\text { Persyaratan Minimal lembaga } \\
\text { Linkage khusus hanya Pola } \\
\text { Channeling }\end{array}$ \\
\hline 1 & CAR & $\begin{array}{l}\text { Setelah memperoleh } \\
\text { pembiayaan }>6 \%\end{array}$ & $\begin{array}{l}\text { Setelah memperoleh } \\
\text { pembiayaan }>6 \%\end{array}$ \\
\hline 2 & Modal disetor & Sesuai ketentuan BI & Sesuai ketentuan BI \\
\hline 3 & Lama Beroperasi & Executing/Channeling: 2 tahun & Channeling: 2 tahun \\
\hline 4 & Scoring & $\begin{array}{l}\text { Executing/Channeling: scoring } \\
\text { minimal kategori Tier 4 (score } \\
\geq 61), \text { selama 2 tahun terakhir }\end{array}$ & $\begin{array}{l}\text { Channeling: scoring minimal } \\
\text { kategori Tier 4 (score } \geq 61), \\
\text { selama 2 tahun terakhir }\end{array}$ \\
\hline 5 & Rasio NPF & $\begin{array}{l}\text { Executing/Channeling: Rasio } \\
\text { NPF Gross }<5 \%\end{array}$ & $\begin{array}{l}\text { Channeling: Rasio NPF Gross }< \\
5 \%\end{array}$ \\
\hline 6 & DER & $\begin{array}{l}\text { Executing: DER }<10 \text { kali } \\
\text { Channeling: tidak } \\
\text { dipersyaratkan }\end{array}$ & $\begin{array}{l}\text { Channeling: tidak } \\
\text { dipersyaratkan }\end{array}$ \\
\hline
\end{tabular}




\begin{tabular}{|c|c|c|c|}
\hline 7 & Legalitas & $\begin{array}{l}\text { Sesuai aturan BI yang berlaku, } \\
\text { yaitu: } \\
\text { a. Surat ijin prinsip dari BI } \\
\text { b. Surat ijin usaha BI } \\
\text { c. Surat ijin usaha dari } \\
\text { Departemen Keuangan } \\
\text { d. TDP, NPWP } \\
\text { e. SITU/ Domisili Usaha }\end{array}$ & $\begin{array}{l}\text { Sesuai at uran BI yang berlaku, } \\
\text { yaitu: } \\
\text { a. Surat ijin prinsip dari BI } \\
\text { b. Surat ijin usaha BI } \\
\text { c. Surat ijin usaha dari } \\
\quad \text { Departemen Keuangan } \\
\text { d. TDP, NPWP } \\
\text { e. SITU/ Domisili Usaha } \\
\end{array}$ \\
\hline 8 & Laporan Keuangan & $\begin{array}{l}\text { a. Audited untuk lembaga } \\
\text { Linkage dengan asset di atas } \\
\text { Rp10Milyar } \\
\text { b. Tahun pertama } \\
\text { diperkenankan menggunakan } \\
\text { akuntan publik bukan } \\
\text { rekanan bank, apabila } \\
\text { laporan keuangan telah } \\
\text { diaudit KAP non rekanan. } \\
\text { Sedangkan tahun berikutnya } \\
\text { wajib menggunakan KAP } \\
\text { rekanan bank. }\end{array}$ & $\begin{array}{l}\text { a. Audited untuk lembaga } \\
\text { Linkage dengan asset di atas } \\
\text { Rp10Milyar } \\
\text { b. Tahun pertama } \\
\text { diperkenankan menggunakan } \\
\text { akuntan publik bukan } \\
\text { rekanan bank, apabila } \\
\text { laporan keuangan telah } \\
\text { diaudit KAP non rekanan. } \\
\text { Sedangkan tahun berikutnya } \\
\text { wajib menggunakan KAP } \\
\text { rekanan bank. }\end{array}$ \\
\hline 9. & Persyaratan lainnya & $\begin{array}{l}\text { a. Tidak termasuk negative list } \\
\text { bank } \\
\text { b. Telah dilakukan pengecekan } \\
\text { data newsletter pada PPATK } \\
\text { atas nama lembaga Linkage } \\
\text { beserta pengurusnya } \\
\text { c. Hasil Trade Checking } \\
\text { terhadap pengurus BPRS } \\
\text { menunjukkan hasil positif } \\
\text { d. Bentuk badan hukum adalah } \\
\text { Perseroan Terbatas (PT) } \\
\text { yang telah disahkan oleh } \\
\text { institusi berwenang } \\
\text { e. Melampirkan curriculum } \\
\text { vitae pengurus dan sertifikat } \\
\text { profesi manajemen senior } \\
\text { lembaga Linkage dari } \\
\text { lembaga sertifikasi } \\
\text { f. Jangka waktu pembiayaan } \\
\text { dari lembaga Linkage kepada } \\
\text { End User tidak melebihi } \\
\text { jangka waktu akad } \\
\text { pembiayaan/kerja sama bank } \\
\text { dengan lembaga Linkage } \\
\text { g. Wajib memiliki Dewan } \\
\text { Pengawas Syariah (DPS) } \\
\text { h. Channeling: Khusus untuk } \\
\text { nasabah/end user golongan } \\
\text { berpendapatan tetap, } \\
\text { lembaga Linkage telah } \\
\text { memiliki Perjanjian Kerja } \\
\text { Sama potong gaji dengan } \\
\text { perusahaan / instansi tempat } \\
\text { nasabah bekerja }\end{array}$ & $\begin{array}{l}\text { a. Tidak termasuk negative list } \\
\text { bank } \\
\text { b. Telah dilakukan pengecekan } \\
\text { data newsletter pada PPATK } \\
\text { atas nama lembaga Linkage } \\
\text { beserta pengurusnya } \\
\text { c. Hasil Trade Checking } \\
\text { terhadap pengurus BPRS } \\
\text { menunjukkan hasil positif } \\
\text { d. Bentuk badan hukum adalah } \\
\text { Perseroan Terbatas (PT) } \\
\text { yang telah disahkan oleh } \\
\text { institusi berwenang } \\
\text { e. Melampirkan curriculum } \\
\text { vitae pengurus dan sertifikat } \\
\text { profesi manajemen senior } \\
\text { lembaga Linkage dari } \\
\text { lembaga sertifikasi } \\
\text { f. Jangka waktu pembiayaan } \\
\text { kepada End User tidak } \\
\text { melebihi jangka waktu akad } \\
\text { pembiayaan/kerja sama bank } \\
\text { dengan lembaga Linkage } \\
\text { g. Khusus untuk nasabah/end } \\
\text { user golongan berpendapatan } \\
\text { tetap, lembaga Linkage telah } \\
\text { memiliki Perjanjian Kerja } \\
\text { Sama potong gaji dengan } \\
\text { perusahaan / instansi tempat } \\
\text { nasabah bekerja }\end{array}$ \\
\hline
\end{tabular}

Sumber: Bank Syariah Mandiri 


\section{Ketentuan Umum Linkage Program}

Terdapat ketentuan pelaksanaan dalam Linkage Program, yaitu ketentuan tentang wewenang memutus, mengacu pada pedoman pembiayaan bank. Bank melakukan analisis on desk dan on site (on the spot), terhadap permohonan pembiayaan dari lembaga Linkage selaku mitra kerja sama dengan menggunakan format analisis pembiayaan yang berlaku di bank. Pengikatan dan penutupan asuransi sesuai dengan aturan yang berlaku di bank.

Dokumen pembiayaan end user untuk pola executing, disimpan oleh lembaga Linkage. Untuk pola channeling, dokumen pembiayaan disimpan di bank. Namun, jika tempat penyimpanan dokumen milik lembaga Linkage dinilai layak menurut ketentuan bank yaitu memiliki sertifikat uji kelayakan brankas dari badan sertifikasi (minimal tahan api) maka dokumen pembiayaan end user dapat disimpan di lembaga Linkage.

Penyimpanan dokumen jaminan end user untuk pola executing, dokumen jaminan disimpan oleh lembaga Linkage. Sedang pola channeling, dokumen jaminan untuk limit ${ }^{-}$Rp 25.000.000,00 disimpan di bank. Namun jika tempat penyimpanan dokumen milik lembaga Linkage dinilai layak menurut ketentuan bank, yaitu memiliki sertifikat uji kelayakan brankas dari badan sertifikasi (minimal tahan api) maka dokumen pembiayaan end user dapat disimpan di lembaga Linkage. Dokumen jaminan untuk limit ${ }^{-} \mathrm{Rp}$ 25.000.000,00 wajib disimpan di bank. Lembaga Linkage diwajibkan untuk mengganti dokumen jaminan yang rusak/hilang. Bank diberikan hak untuk melakukan pemeriksaan dokumen setiap saat.

Persyaratan self financing (untuk akad murābaḥah dan mushārakah) yaitu tidak boleh bersumber dari pinjaman pihak ketiga, porsi self financing yang harus dipenuhi adalah sebesar minimal 30\% untuk murābạ̣ah dan mushārakah yang dihitung berdasarkan kebutuhan pembiayaan.

Jangka waktu penarikan/pencairan yaitu maksimum 1 (satu) tahun terhitung sejak penandatanganan akad pembiayaan dan/atau Perjanjian Kerja Sama (PKS). Penarikan/pencairan pertama dilakukan maksimum 3 (tiga) bulan sejak penandatanganan akad dan/atau PKS, apabila nasabah tidak dapat melakukan penarikan/pencairan limit pembiayaan untuk pertama kali 
dalam waktu maksimum 3 (tiga) bulan sejak penandatanganan akad dan PKS. Apabila melebihi 3 (tiga) bulan, maka nasabah tidak dapat menggunakan limit yang tersedia. Karena itu, nasabah harus mengajukan permohonan limit pembiayaan baru atau perpanjangan masa penarikan.

Ketentuan mengenai margin/bagi hasil, denda (keterlambatan pembayaran angsuran pokok dan margin/bagi hasil) dan biaya administrasi sesuai ketentuan yang berlaku di bank.

\section{Ketentuan Khusus Linkage Program}

Selain ketentuan umum, juga terdapat beberapa ketentuan khusus, yaitu ketentuan yang berlaku pada pola executing, diberikan hanya kepada lembaga Linkage untuk tujuan modal kerja dan/atau investasi. Adapun jenis agunan adalah sebagai berikut:

Tabel 2.2

Jenis Agunan

\begin{tabular}{|c|c|}
\hline Pembiayaan Modal Kerja & Pembiayaan Investasi \\
\hline $\begin{array}{l}\text { 1) Piutang dari limit yang dibiayai bank } \\
\text { (dalam akta Fidusia terdapat klausula } \\
\text { subrogasi jaminan dari nasabah } \\
\text { lembaga Linkage/end user dengan } \\
\text { hak preference kepada bank). } \\
\text { 2) Piutang existing dari pembiayaan } \\
\text { yang telah berjalan di lembaga } \\
\text { Linkage dengan kolektabilitas lancar } \\
\text { dan belum dijaminkan kepada pihak } \\
\text { lain. }\end{array}$ & $\begin{array}{l}\text { Proyek/obyek yang dibiayai } \\
\text { dengan nilai minimal jaminan } \\
\text { sebesar } 100 \% \text { dari limit } \\
\text { pembiayaan. }\end{array}$ \\
\hline \multicolumn{2}{|c|}{ Cash collateral milik lembaga Linkage at au pengurus yang diikat secara gadai } \\
\hline \multicolumn{2}{|c|}{$\begin{array}{l}\text { Harta tetap milik lembaga Linkage atau pengurus, wajib di -cover asuransi } \\
\text { kerugian dengan Banker's Clause BSM. }\end{array}$} \\
\hline \multicolumn{2}{|c|}{ Penjaminan pembiayaan dari Lembaga Penjamin rekanan bank. } \\
\hline \multicolumn{2}{|c|}{$\begin{array}{l}\text { Personal Guarantee pengurus lembaga Linkage (minimal } 1 \text { orang direksi/ } \\
\text { komisaris/pemegang saham mayoritas). }\end{array}$} \\
\hline
\end{tabular}

Sumber: Bank Syariah Mandiri

Pengikatan agunan dilakukan untuk dan atas nama bank dan penutupan asuransi dilakukan sesuai dengan ketentuan yang berlaku pada 
bank. Kemudian pencairan pembiayaan dilakukan berdasarkan daftar nominative Nasabah/end user yang diajukan oleh lembaga Linkage. Dan terakhir, limit pembiayaan ditetapkan berdasarkan scoring lembaga Linkage yang telah diverifikasi cabang. Adapun ketentuan limit pembiayaan lembaga Linkage ditetapkan sebagai berikut:

Tabel 2.3

Ketentuan Limit Pembiayaan Lembaga Linkage

\begin{tabular}{|c|l|}
\hline Score & \multicolumn{1}{|c|}{ Limit maksimal } \\
\hline$\geq 91$ & 10 kali modal disetor \\
\hline $81-90$ & 8 kali modal disetor \\
\hline $71-80$ & 7 kali modal disetor \\
\hline $61-70$ & 6 kali modal disetor \\
\hline
\end{tabular}

Sumber: Ketentuan Bank Syariah Mandiri

Sedangkan ketentuan yang berlaku pada pola channeling yaitu pembiayaan dapat dilakukan melalui semua lembaga Linkage. Pembiayaan pola channeling melalui lembaga Linkage non syariah, harus dengan akad syariah, sedang lembaga Linkage hanya bertindak sebagai agen/wali. Kemudian terkait dengan pencatatan pembiayaan di bank itu merupakan pembiayaan UMK/end user dan di lembaga Linkage pada off balance sheet. Sebagai imbal jasa, lembaga Linkage berhak menerima ujrah/fee. Adapun penentuan limit pembiayaan pola channeling disesuaikan dengan kebutuhan end user dengan memperhitungkan fasilitas existing baik dari bank maupun dari lembaga keuangan lainnya sebagai faktor pengurang. Dan terakhir, sasaran nasabah/end user dapat berupa golongan berpendapatan tetap (Golbertap), bukan golongan berpendapatan tetap (Non Golbertab), dan golongan Pensiunan.

Ketentuan pembiayaan berdasarkan limit nasabah/end user yaitu limit Rp. 25.000.000,00 per nasabah/end user mengikuti ketentuan lembaga Linkage, jika dinilai telah memenuhi ketentuan standar yang berlaku di bank. Limit $^{-}$Rp. 25.000.000,00 per nasabah/end user, mengikuti ketentuan yang berlaku di bank. 
Ketentuan jaminan untuk pola channeling adalah sebagai berikut:

Tabel 2.4

Ketentuan Jaminan

\begin{tabular}{|c|c|c|c|}
\hline No & Uraian & \multicolumn{2}{|c|}{ Ketentuan Agunan } \\
\hline 1) & Pembiayaan investasi & \multicolumn{2}{|c|}{ Project atau object yang akan dibiayai } \\
\hline 2) & \multicolumn{3}{|l|}{ Pembiayaan modal kerja } \\
\hline \multirow[t]{4}{*}{ a) } & \multirow{4}{*}{$\begin{array}{l}\text { End user Golbertab \& } \\
\text { golongan pensiunan } \\
\text { (1) Dipersyaratkan } \\
\text { lembaga Linkage harus } \\
\text { memiliki kerja sama } \\
\text { potong gaji dengan } \\
\text { perusahaan/ instansi } \\
\text { tempat nasabah/end } \\
\text { user bekerja. } \\
\text { (2) Dokumen asli SK } \\
\text { pengangkatan, surat } \\
\text { keterangan gaji, taspen } \\
\text { (PNS) dari end user. } \\
\text { (3) Nasabah/end user } \\
\text { wajib di-cover asuransi } \\
\text { jiwa. }\end{array}$} & Limit Pembiayaan & $\begin{array}{l}\text { Agunan yang } \\
\text { dipersyaratkan }\end{array}$ \\
\hline & & $\leq \mathrm{Rp} 25.000 .000,00$ & $\begin{array}{l}\text { Tidak dipersyaratkan } \\
\text { agunan }\end{array}$ \\
\hline & & $>\operatorname{Rp} 25.000 .000,00$ & $\begin{array}{l}\text { Agunan tambahan } \\
\text { berupa: } \\
\text { (1) Rumah/ mobil/ } \\
\text { sepeda motor } \\
\text { atau, } \\
\text { (2) Asuransi } \\
\text { penjaminan } \\
\text { pembiayaan }\end{array}$ \\
\hline & & $\begin{array}{l}\text { Pembiayaan khusus } \\
\text { untuk pembelian } \\
\text { rumah/mobil/ } \\
\text { sepeda motor. }\end{array}$ & $\begin{array}{l}\text { Rumah/mobil/ } \\
\text { sepeda motor yang } \\
\text { dibiayai }\end{array}$ \\
\hline \multirow[t]{3}{*}{ b) } & \multirow{3}{*}{$\begin{array}{l}\text { End user non Golbertab } \\
\text { (peorangan atau badan } \\
\text { usaha). } \\
\text { (1) Collateral coverage } \\
\text { wajib minimal } 100 \% \\
\text { dari limit pembiayaan } \\
\text { (2) Nasabah/end user } \\
\text { wajib di-cover } \\
\text { asuransi jiwa. }\end{array}$} & Limit pembiayaan & $\begin{array}{l}\text { Agunan yang } \\
\text { dipersyaratkan }\end{array}$ \\
\hline & & Rp25.000.000,00 & $\begin{array}{l}\text { Jaminan yang harus } \\
\text { diserahkan oleh end } \\
\text { user sesuai ketentuan } \\
\text { yang berlaku pada } \\
\text { BPR/S }\end{array}$ \\
\hline & & $>\operatorname{Rp} 25.000 .000,00$ & $\begin{array}{l}\text { Nilai jaminan yang } \\
\text { harus diserahkan } \\
\text { oleh end user } \\
\text { minimal sebesar } \\
100 \% \text { dari limit } \\
\text { pembiayaan, sesuai } \\
\text { dengan ketentuan } \\
\text { yang berlaku di bank. }\end{array}$ \\
\hline \multicolumn{4}{|c|}{$\begin{array}{l}\text { Note: } \\
\text { Pengikatan agunan untuk dan atas nama bank dan penutupan asuransi sesuai } \\
\text { dengan ketentuan yang berlaku pada bank. }\end{array}$} \\
\hline
\end{tabular}

Sumber: Ketentuan Bank Syariah Mandiri 
Pemeriksaan dokumen dilakukan secara sampling minimal sebesar $20 \%$ terhadap calon nasabah channeling melalui lembaga Linkage dilakukan oleh cabang secara periodik paling lambat 6 (enam) bulan sekali. Namun, setiap saat juga dapat dilakukan apabila rasio NPF memburuk.

\section{Margin Bagi Hasil}

Margin bagi hasil (price) pada pembiayaan Linkage Program dengan pola executing dan channeling ditetapkan Bank Syariah Mandiri sebagai berikut:

Pola Executing:

Tabel 2.5

Margin Bagi Hasil Pola Executing

\begin{tabular}{|c|c|c|c|}
\hline No & & Uraian & Ketentuan Price \\
\hline a. & Per & biayaan investasi & $\begin{array}{l}\text { Price sesuai dalam SE Price } \\
\text { Pembiayaan yang berlaku dan } \\
\text { perubahannya. }\end{array}$ \\
\hline \multirow[t]{7}{*}{ b. } & \multicolumn{2}{|c|}{ Pembiayaan modal kerja } & \\
\hline & \multirow[t]{3}{*}{ 1) } & $\begin{array}{ll}\text { End user } & \text { Golongan } \\
\text { Berpendapatan Tetap } & \end{array}$ & \\
\hline & & $\begin{array}{l}\text { a) Pegawai PNS, anggota } \\
\text { Pegawai PNS, anggota } \\
\text { TNI/POLRI, Lembaga } \\
\text { Negara dan BUMN/D }\end{array}$ & $\begin{array}{l}\text { Mengikuti tiering price } \\
\text { pembiayaan consumer yang } \\
\text { berlaku dan perubahannya. }\end{array}$ \\
\hline & & b) Pegawai swasta & $\begin{array}{l}\text { Mengikuti tiering price } \\
\text { pembiayaan consumer yang } \\
\text { berlaku dan perubahannya. }\end{array}$ \\
\hline & 2) & $\begin{array}{l}\text { End user bukan Golongan } \\
\text { Berpendapatan Tetap } \\
\text { (perorangan atau badan usaha) }\end{array}$ & $\begin{array}{l}\text { Single price untuk pembiayaan } \\
\text { komersial (BLR + risk premium) }\end{array}$ \\
\hline & 3) & End user Golongan Pensiunan & $\begin{array}{l}\text { Mengikuti tiering price } \\
\text { pensiunan yang berlaku dan } \\
\text { perubahannya. }\end{array}$ \\
\hline & 4) & $\begin{array}{l}\text { End user merupakan kombinasi } \\
\text { butir 1), 2), dan 3) di atas }\end{array}$ & $\begin{array}{l}\text { Single price unt uk pembiayaan } \\
\text { komersial (BLR + risk premium) }\end{array}$ \\
\hline
\end{tabular}

Sumber: Ketentuan Bank Syariah Mandiri 
Pola Channeling:

Tabel 2.6

Margin Bagi Hasil Pola Channeling

\begin{tabular}{|c|c|c|c|}
\hline No & & Uraian & Ketentuan price \\
\hline \multirow[t]{6}{*}{ a. } & \multicolumn{2}{|c|}{ Pembiayaan investasi } & \\
\hline & \multirow[t]{3}{*}{ 1) } & $\begin{array}{l}\text { End user Golongan } \\
\text { Berpendapatan Tetap }\end{array}$ & \\
\hline & & $\begin{array}{l}\text { a) Pegawai PNS, anggota } \\
\text { Pegawai PNS, anggota } \\
\text { TNI/POLRI, Lembaga } \\
\text { Negara dan BUMN/D }\end{array}$ & $\begin{array}{l}\text { Mengikuti tiering price } \\
\text { pembiayaan consumer yang } \\
\text { berlaku dan perubahannya. }\end{array}$ \\
\hline & & b) Pegawai swasta & $\begin{array}{l}\text { Mengikuti tiering price } \\
\text { pembiayaan consumer yang } \\
\text { berlaku dan perubahannya. }\end{array}$ \\
\hline & 2) & $\begin{array}{l}\text { End user bukan Golongan } \\
\text { Berpendapatan Tetap } \\
\text { (perorangan atau badan usaha) }\end{array}$ & $\begin{array}{l}\text { Price sesuai dalam SE Price } \\
\text { Pembiayaan yang berlaku dan } \\
\text { perubahannya }\end{array}$ \\
\hline & 3) & End user Golongan Pensiunan & $\begin{array}{l}\text { Mengikuti tiering price dalam SE } \\
\text { pensiunan yang berlaku dan } \\
\text { perubahannya. }\end{array}$ \\
\hline \multirow[t]{6}{*}{ b. } & \multicolumn{2}{|c|}{ Pembiayaan modal kerja } & \\
\hline & \multirow[t]{3}{*}{ 1) } & $\begin{array}{l}\text { End user Golongan } \\
\text { Berpendapatan Tetap }\end{array}$ & \\
\hline & & $\begin{array}{l}\text { a) Pegawai PNS, anggota } \\
\text { Pegawai PNS, anggota } \\
\text { TNI/POLRI, Lembaga } \\
\text { Negara dan BUMN/D }\end{array}$ & $\begin{array}{l}\text { Mengikuti tiering price } \\
\text { pembiayaan consumer yang } \\
\text { berlaku dan perubahannya. }\end{array}$ \\
\hline & & b) Pegawai swasta & $\begin{array}{l}\text { Mengikuti tiering price } \\
\text { pembiayaan consumer yang } \\
\text { berlaku dan perubahannya. }\end{array}$ \\
\hline & 2) & $\begin{array}{l}\text { End user bukan Golongan } \\
\text { Berpendapatan Tetap } \\
\text { (perorangan atau badan usaha) }\end{array}$ & $\begin{array}{l}\text { Single price unt uk pembiayaan } \\
\text { komersial (BLR + risk premium) }\end{array}$ \\
\hline & 3) & End user Golongan Pensiunan & $\begin{array}{l}\text { Mengikuti tiering price dalam SE } \\
\text { pensiunan yang berlaku dan } \\
\text { perubahannya. }\end{array}$ \\
\hline
\end{tabular}

Sumber: Ketentuan Bank Syariah Mandiri

Adapun jangka waktu pembiayaan untuk modal kerja dan investasi ditetapkan masing-masing maksimal 5 (lima) tahun. 


\section{Perkembangan Linkage Program di Bank Syariah Mandiri Cabang Salatiga}

Perkembangan yang terjadi pada Linkage Program di Bank Syarah Mandiri Cabang Salatiga sangat baik. Nominal pembiayaan yang sudah diajukan mulai sekitar Rp200 juta hingga milyaran rupiah (Wawancara dengan Bapak Arinengwang, Manager Marketing, pada 2 Juli 2012).

Bank Syariah Mandiri (BSM) Salatiga menetapkan target pencapaian pembiayaan Linkage Program per Juni 2012 sebesar Rp 5.430.000.000, per September 2012 sebesar Rp 8.145.800.000, dan per Desember 2012 sebesar Rp10.861.060.000.000.

Target tersebut merupakan angka yang kecil bagi wilayah Salatiga yang masih sedikit mendapatkan suntikan dana bagi lembaga Linkage yang ada. Selama ini, AO (Account Officer) telah terbukti dapat mencapai target tersebut dalam jangka waktu yang lebih cepat.

\section{Skema Pembiayaan Linkage Program dengan Pola Executing di BSM Salatiga}

Pembiayaan pola executing adalah pembiayaan UMK yang langsung diberikan bank kepada koperasi/koperasi syariah atau BPRS. Berikut skema, prosedur dan analisis pola executing yang diambil sampelnya diambil dari salah satu lembaga Linkage yaitu koperasi, yang mana pada BMT maupun BPRS juga berskema sama. 
Skema Pola Executing:
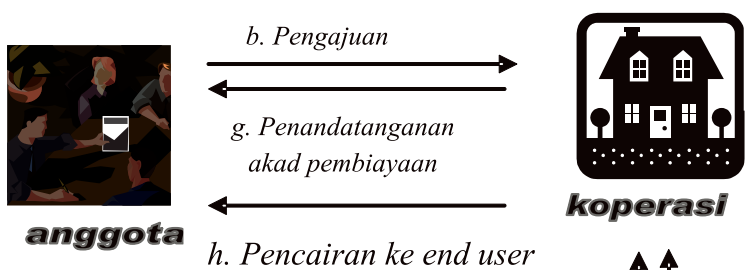

c. Proses komite
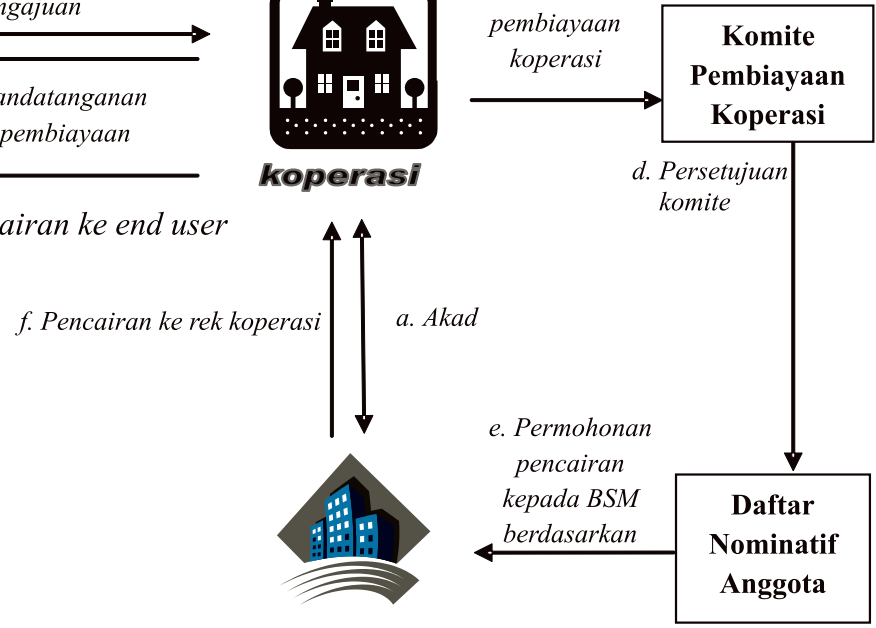

\section{BSM}

\section{Gambar 3.1}

Skema Pola Executing

Sumber: Bank Syariah Mandiri

Analisis pengendalian risiko pembiayaan Linkage Program dengan pola executing di Bank Syariah Mandiri Cabang Salatiga yang kemungkinan terjadi (wawancara pada 26 Juni 2012 dengan Bapak Patria, Account Officer (AO) di Bank Syariah Mandiri Cabang Salatiga) meliputi: 1) Analisis aspek yuridis; Analisis ini menyajikan data mengenai legalitas pendirian usaha, legalitas usaha, dan legalitas permohonan pembiayaan oleh nasabah. Risiko yang mungkin terjadi yaitu legalitas usaha nasabah tidak sah, legalitas usaha telah habis masa berlakunya, dan permohonan yang diajukan tidak sah secara hukum. Pengendalian risiko (mitigasi) dari risiko tersebut yaitu legalitas pendirian perusahaan nasabah harus mendapatkan pengesahan dari Departemen Koperasi, Pengusaha Kecil dan Menengah pada wilayah lembaga Linkage berada; 2) Analisis aspek karakter dan manajemen; Aspek ini menyajikan aspek karakter yang meliputi reputasi lembaga Linkage dan profesionalisme pengurus. Sedangkan aspek manajemen meliputi struktur organisasi nasabah, prosedur operasional usaha nasabah, strategi usahanya, kinerja lembaga Linkage, serta Rapat Anggota Tahunan-nya. Kemungkinan 
risiko yang terjadi yaitu tidak dikelolanya usaha dengan baik dan tidak difungsikannya RAT, dan usaha nasabah tidak memiliki kinerja yang baik. Pengendalian risikonya yaitu dengan melakukan monitoring rutin tentang kinerja koperasi oleh AO dan diikutsertakannya AO dalam acara RAT, usaha nasabah diusahakan selalu mengalami peningkatan dari tahun ke tahun dan mengembangkan potensi yang mungkin bisa dikembangkan; 3) Analisis aspek teknis; Aspek ini menganalisis tentang unit usaha lembaga Linkage, produk simpan pinjam di lembaga Linkage, perkembangan jumlah kantor cabang yang dimiliki lembaga Linkage, dan seberapa jumlah karyawan yang bekerja pada lembaga Linkage tersebut. Risiko yang mungkin terjadi, yaitu teknis pelaksanaan kegiatan usaha terhambat karena faktor prosedur, IT, dan keterbatasan knowledge. Mitigasi risikonya, yaitu perangkat prosedur perusahaan yang dibentuk harus lengkap mulai dari rancangan produk, hingga monitoring dan evaluasinya, harus disediakan sistem IT yang mendukung operasional sehari-hari, koperasi hendaknya dipimpin oleh pengurus koperasi yang memiliki kompetensi dan didukung oleh karyawan dengan sistem rekrutmen yang baik sehingga mendapatkan kualitas pegawai yang memadai atau siap pakai); 4) Analisis aspek pemasaran; Menganalisis data nasabah mengenai prospek usaha dan target pasar yang dituju oleh lembaga Linkage serta tingkat persaingan usaha. Risiko yang mungkin terjadi, yaitu lembaga Linkage kalah dalam persaingan mendapatkan pasar usaha simpan pinjam. Mitigasinya, melihat kondisi pasar usaha lembaga Linkage saat ini sudah jenuh apa belum, dan melihat apakah lembaga Linkage tersebut mempunyai banyak keunggulan baik dalam hal produk maupun pengalaman para pegawainya dalam menjalankan usaha simpan pinjam; 5) Analisis aspek keuangan; Menganalisis data past performance keuangan nasabah, seperti laporan keuangan, analisis trend terkait dengan jumlah asset lembaga Linkage, dana pihak ketiga yang mereka miliki, perkembangan hutang, modal, dan SHU/laba yang diperoleh. Selain itu juga dilakukan analisis terkait rasio likuiditas nasabah, leverage, rentabilitas, efisiensi. Analisis aspek keuangan ini juga menganalisis kolektabilitas nasabah. Setelah melihat hasil analisis past performance nasabah, berikutnya dilakukan analisis pada penyaluran aktivitas keuangan lembaga Linkage di Bank Syariah Mandiri cabang yang lainnya. Tidak hanya cukup sampai di situ, AO juga menganalisis seberapa kebutuhan dana untuk usaha lembaga Linkage, dan 
bagaimana analisis pola, skim, jangka waktu, dan price pembiayaan yang sesuai serta repayment capacitynya; 6) Analisis Aspek Jaminan; Di dalamnya menganalisis jaminan yang diberikan lembaga Linkage sesuai persyaratan yang ditentukan pada peraturan Bank Syariah Mandiri, yaitu agunan utama yang merupakan piutang yang diikat secara fidusia, bukan merupakan piutang existing yang diikat fidusia oleh bank lain. Piutang yang akan diikat secara fidusia merupakan pembiayaan yang akan diberikan kepada anggota calon peminjam yang dananya diperoleh lembaga Linkage dari Bank Syariah Mandiri pada pengajuan pembiayaan sesuai daftar nominatif. Risiko yang mungkin terjadi, yaitu kemungkinan jaminan tidak dapat diikat sempurna, jaminan tidak mengcover, dan ketidakjelasan kepemilikan yang menimbulkan konsekuensi hukum bagi Bank Syariah Mandiri. Pengendalian risikonya, yaitu jaminan diikat secara fidusia, APHT dengan nilai minimal sebesar 125\% dari limit pembiayaan dan gadai kepada Bank Syariah Mandiri, nilai jaminan dihitung secara konservatif dan harus mengcover pembiayaan, serta menghindari ketidakjelasan kepemilikan dengan menggunakan objek jaminan yang dimiliki oleh pengurus koperasi.

\section{Skema Pembiayaan Linkage Program dengan Pola Channeling di BSM Salatiga}

Pembiayaan pola channeling adalah pembiayaan yang diberikan bank kepada UMK melalui BPR/S yang bertindak sebagai agen/wali. Pencatatan di bank sebagai pembiayaan ke UMK/end user dan di BPR/S pada off balance sheet. BPR/S sebagai agen berhak menerima ujrah/fee. Berdasarkan update peraturan intern BSM, mulai bulan Juni 2012, BSM tidak diperkenankan menyalurkan pembiayaan kepada BPR. 


\section{Skema Pola Channeling}

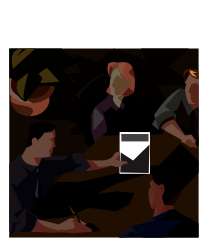

Anggota b. Mengajukan fasilitas

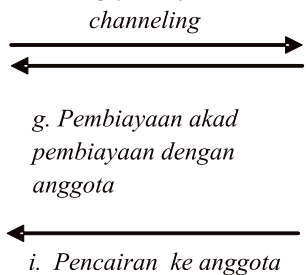

$$
\text { (a) }
$$

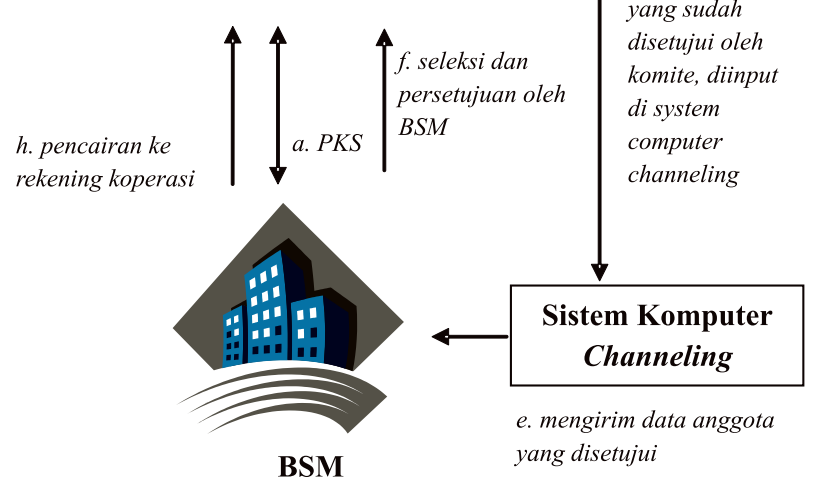

c. NAP end user diajukan

ke Komite Pembiayaan

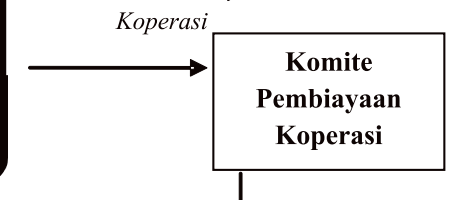

d. anggota

yang sudah

disetujui oleh

komite, diinput

di system

computer

channeling

\section{Gambar 3.2 \\ Skema Pola Channeling \\ Sumber: Bank Syariah Mandiri}

Analisis Pengendalian Risiko Pembiayaan Linkage Program dengan Pola Channeling di Bank Syariah Mandiri Cabang Salatiga hampir sama dengan analisis yang dilakukan pada pola executing, yang membedakan hanya penyelesaian masalah pada jenis risikonya.

\section{Perbedaan Pola Executing dan Channeling di BSM Salatiga}

Selain skema dan prosedur, ada beberapa perbedaan lain yang membedakan antara pola executing dan pola channeling, yaitu: 1) Nasabah pembiayaan Linkage Program untuk pola executing hanya diperuntukkan kepada KSP, KSU, BMT, dan KJKS. Sedangkan untuk pola channeling boleh untuk semua lembaga Linkage. Selanjutnya nasabah disebut lembaga Linkage; 2) Lembaga Linkage berperan sebagai penyedia dana bagi end 
user, dengan plafon yang besar (misal 1 miliar) sebagai modal kerjanya untuk kemudian disalurkan pada anggota lembaga Linkage (end user) dalam bentuk pembiayaan yang lain yang plafonnya lebih kecil. Sedangkan dalam pola channeling, lembaga Linkage hanya berperan sebagai agen/wali atau perantara pembiayaan anggota koperasi dengan bank, sehingga plafonnya di bank kecil-kecil. Lembaga Linkage mendapatkan imbalan dari end user atas jasa perantaraan tersebut; 3) Dalam pola executing, bank hanya diberikan daftar nominatif end user yang mengajukan pembiayaan. Sedangkan dalam pola channeling bank mengenal end user sehingga mengetahui karakter nasabah dan dapat menentukan keputusan pembiayaan dengan lebih mudah; 4) Dalam pola executing, end user lebih mudah dan sederhana dalam pengajuan pembiayaan sehingga wakt unya pun lebih cepat. Sedangkan dalam pola channeling, end user harus mengikuti banyak prosedur yang bisa dianggap rumit oleh end user dan memakan waktu yang lebih lama; 5) Dept to Equity Ratio (DER) untuk pola executing dipersyaratkan maksimal 10 kali. Sedangkan untuk pola channeling tidak dipersyaratkan; 6) Dalam pola executing, keputusan ditentukan oleh lembaga Linkage. Sedangkan pola channeling, keputusan pembiayaan ditentukan langsung oleh bank; 7) Penyimpanan jaminan end user dengan pola executing, jaminan end user dipegang oleh lembaga Linkage. Dengan pola channeling, jaminan end user langsung dipegang oleh bank; 8) Penyimpanan dokumen pembiayaan pada pola executing disimpan oleh lembaga Linkage terkait. Sedangkan untuk penyimpanan dokumen pembiayaan pada pola channeling disimpan di bank, kecuali jika lembaga Linkage terkait memiliki ruang penyimpanan yang dianggap layak oleh bank; 9) Jenis akad yang digunakan untuk pembiayaan dengan pola executing yaitu muḍārabah wa al-murābahah, sedangkan untuk pola channeling, tidak membedakan apakah itu lembaga Linkage syariah atau non syariah, keduanya tetap menggunakan akad dengan prinsip syariah, yaitu akad wakālah wa al-murābaḥah/ijārah.

Dilihat dari segi pengendalian risiko, antara pola executing dan channeling sebenarnya tidak ada yang berbeda. Perbedaan suatu pengendalian risiko (mitigasi) hanya tergantung pada risiko yang kemungkinan terjadi dalam kasus tertentu. Sedangkan yang menjadi perbedaan antara pola executing dan channeling, selain skema dan prosedur, secara garis besar adalah sebagai berikut: 
Tabel 4.1

Perbedaan Pola Executing dan Channeling

\begin{tabular}{|l|l|l|}
\hline \multicolumn{1}{|c|}{ Item } & \multicolumn{1}{|c|}{ Pola Executing } & \multicolumn{1}{c|}{ Pola Channeling } \\
\hline Nasabah & $\begin{array}{l}\text { Hanya lembaga } \\
\text { Linkage syariah dan } \\
\text { koperasi }\end{array}$ & Boleh semua lembaga Linkage \\
\hline $\begin{array}{l}\text { Peran lembaga } \\
\text { Linkage }\end{array}$ & $\begin{array}{l}\text { Sebagai penyedia } \\
\text { dana bagi end user. }\end{array}$ & $\begin{array}{l}\text { Sebagai wali/perantara bagi } \\
\text { user. }\end{array}$ \\
\hline $\begin{array}{l}\text { Informasi } \\
\text { tentang end user }\end{array}$ & $\begin{array}{l}\text { Hanya diberikan } \\
\text { daftar nominatifnya }\end{array}$ & Mengetahui semua data end user \\
\hline $\begin{array}{l}\text { Pandangan } \\
\text { prosedur dari } \\
\text { segi end user }\end{array}$ & $\begin{array}{l}\text { Mudah, sederhana, } \\
\text { dan waktu lebih } \\
\text { singkat. }\end{array}$ & $\begin{array}{l}\text { Banyak prosedur, agak terbilang } \\
\text { rumit, waktu lebih lama. }\end{array}$ \\
\hline $\begin{array}{l}\text { Dept to Equity } \\
\text { Ratio (DER) }\end{array}$ & Maksimal $<10$ kali & Tidak dipersyaratkan \\
\hline $\begin{array}{l}\text { Keputusan } \\
\text { pembiayaan end } \\
\text { user }\end{array}$ & $\begin{array}{l}\text { Ditentukan oleh } \\
\text { lembaga Linkage }\end{array}$ & Ditentukan oleh bank \\
\hline $\begin{array}{l}\text { Penyimpanan } \\
\text { jaminan } \\
\text { user }\end{array}$ & $\begin{array}{l}\text { Disimpan lembaga } \\
\text { Linkage }\end{array}$ & $\begin{array}{l}\text { Untuk jumlah nominal } \leq \text { Rp. } \\
\text { 25.000.000,00 dapat disimpan di } \\
\text { lembaga Linkage asalkan memiliki } \\
\text { sertifikat uji kelayakan brankas, } \\
\text { diatas nominal tersebut wajib } \\
\text { disimpan di bank }\end{array}$ \\
\hline $\begin{array}{l}\text { Penyimpanan } \\
\text { dokumen } \\
\text { pembiayaan end } \\
\text { user }\end{array}$ & $\begin{array}{l}\text { Disimpan lembaga } \\
\text { Linkage }\end{array}$ & $\begin{array}{l}\text { Disimpan di bank, namun jika } \\
\text { lembaga Linkage mempunyai tempat } \\
\text { yang dinilai layak, maka dokumen } \\
\text { tersebut boleh disimpan lembaga } \\
\text { Linkage }\end{array}$ \\
\hline $\begin{array}{l}\text { Jenis akad } \\
\text { akaupun nasabah lembaga Linkage } \\
\text { akad muadāabah wa } \\
\text { al-murābahahah }\end{array}$ & $\begin{array}{l}\text { Sudah pasti } \\
\text { menggunakan } \\
\text { nongariah, tetap harus } \\
\text { menggunakan akad syariah, yaitu } \\
\text { akad wakāahah wa al- } \\
\text { murābahah/ijārah }\end{array}$ \\
\hline
\end{tabular}

Sumber: Bank Syariah Mandiri

Jumlah nasabah pembiayaan Linkage Program sampai dengan pertengahan Juni 2012, untuk yang memilih pola executing ada 11 nasabah dengan total pembiayaan hampir mancapai Rp15milyar, sedangkan untuk pola channeling ada 2 nasabah dengan total pembiayaan Rp1,3milyar (wawancara dengan Bapak Patria (AO) dan Bapak Yosep (marketing) pada 29 Juni 2012). 
Kemudian pengamatan pada data yang tersedia sampai dengan akhir Juni 2012, dari target yang ditetapkan per Juni 2012 yaitu Rp 5.430.000.000 sudah tercapai $128,95 \%$ nya. Nasabah yang terdaftar dalam pembiayaan Linkage Program ini adalah koperasi-koperasi yang ada di Salatiga dan sekitarnya.

Hal ini jika dibandingkan dengan target yang ditetapkan hasilnya sangat bagus, pembiayaan Linkage Program sangat diminati nasabahnya.

Dengan melihat perbedaan tersebut, dapat dilihat bahwa nasabah (end user) lebih suka memanfaatkan pembiayaan Linkage Program dengan menggunakan pola executing. Hal ini terlihat dari jumlah nasabah Linkage Program, lebih dari $80 \%$ nya merupakan nasabah dengan pola executing.

Skema dan prosedur untuk pembiayaan Linkage Program dengan pola executing tergolong mudah dan sederhana untuk nasabah lembaga Linkage. Hal ini sangat membantu nasabah sebagai lembaga kedua penyalur dana, sehingga pembiayaan yang ingin diajukan oleh end user yang berlokasi jauh dari Bank Syariah Mandiri maupun yang ingin mengajukan melalui lembaga Linkage dengan alasan karena ingin lebih sederhana dalam proses pembiayaannya, dapat terpenuhi.

Skema dan prosedur untuk pembiayaan Linkage Program dengan pola channeling lebih rumit dijalankan. Keamanan dan kenyamanan bank dalam pembiayaan memang lebih terjamin, tetapi memakan proses yang lama dan tenaga yang lebih untuk penyaluran pembiayaan tersebut. Hal ini membuat end user lebih lama juga mendapatkan dana cair yang dibutuhkan.

\section{Penutup}

Berdasarkan uraian dari analisis pada bab sebelumnya, maka dapat disimpulkan bahwa skema dan prosedur untuk pembiayaan Linkage Program dengan pola executing di BSM Salatiga tergolong mudah dan sederhana untuk nasabah lembaga Linkage. Hal ini sangat membantu nasabah sebagai lembaga kedua penyalur dana, sehingga pembiayaan yang ingin diajukan oleh end user yang berlokasi jauh dari Bank Syariah Mandiri maupun yang ingin mengajukan melalui lembaga Linkage dengan alasan karena ingin lebih sederhana dalam proses pembiayaannya, dapat terpenuhi. 
Sedangkan skema dan prosedur untuk pembiayaan Linkage Program dengan pola channeling di BSM Salatiga lebih rumit dijalankan. Keamanan dan kenyamanan bank dalam pembiayaan memang lebih terjamin, tetapi memakan proses yang lama dan tenaga yang lebih untuk penyaluran pembiayaan tersebut. Hal ini membuat end user lebih lama juga mendapatkan dana cair yang dibutuhkan.

Dilihat dari segi pengendalian risiko, antara pola executing dan channeling di BSM Salatiga sebenarnya tidak ada yang berbeda. Perbedaan suatu pengendalian risiko (mitigasi) hanya tergantung pada risiko yang kemungkinan terjadi dalam kasus tertentu.

\section{Daftar Pustaka}

Arifin, Zainul. 2002. Dasar-Dasar Manajemen Bank Syariah. Jakarta: Pustaka Alvabet.

Basuki, Orin. 2011. "Cara Mendapatkan Kredit dari Bank dan Kiat-Kiat Sukses Bagi Pemula". Artikel diterbitkan (online), edisi 16 Maret 2011 (http://apkliindo.blogspot.com/2011/03/cara-mendapatkankredit-dari-bank-dan.html, diakses 14 Juni 2012).

Farika. 2008. Aplikasi Pembiayaan Kongsi Pemilikan Rumah Syariah pada BMT Ahmad Yani Solo. Skripsi tidak diterbitkan. Solo: Universitas STAIN Solo.

Hosen, Muhammad Nadratuzzaman, dkk. 2008. Bank-Ku Syariah. Jakarta: Pusat Komunikasi Ekonomi Syariah (pkes publishing) e-book.

Januar, TB Ardi. 2012. "UKM Lebih Gigih Hadapi Kemerosotan Usaha". Artikel diterbitkan dalam Okezone, (Online), economy-sektor riil (http://economy.okezone.com/read/2012/04/17/320/613477/ukmlebih-gigih-hadapi-kemerosotan-usaha, diakses 14 Juni 2012).

Kumara, Rian, 2010, Analisis Uji Beda Kinerja BPR yang Mengikuti Linkage Program dengan BPR yang Tidak Mengikuti Linkage Program pada Wilayah DPC Depok, Skripsi diterbitkan. Jakarta: Jurusan Akuntansi Universitas Gunadarma, (Online), (http://library.gunadarma.ac.id/ repository/read/27934/20206809, diakses 14 Juni 2012).

Misbach, Muzamil. 2010. Sinergi Antara Lembaga Keuangan Syariah dalam Memajukan Usaha Kecil. Jurnal diterbitkan. Economics Journal It's a capital mistake to theorize before one has data, (Online), (http:// economicsjurnal.blogspot.com/2010_06_12_archive.html, diakses 14 Juni 2012). 
Muhammad, 2002. Manajemen Bank Syariah. Yogyakarta: Unit Penerbit dan Percetakan (UPP) AMP YKPN.

Nabhan, Faqih. 2012. Pengembangan Kapabilitas Kolaborasi Dinamis dan Pengaruhnya Terhadap Kinerja Bisnis, Disertasi tidak diterbitkan. Semarang: Program Pasca Sarjana Universitas Diponegoro.

Sudarsono, Heri dan Hendi Yogi Prabowo. 2004. Istilah-Istilah Bank dan Lembaga Keuangan Syariah. Yogyakarta: UII Press Yogyakarta. 